\title{
PENGARUH GAYA MENGAJAR DAN MOTOR EDUCABILITY TERHADAP PASSING ATAS BOLAVOLI PADA SISWA PUTRA SMP GAJAH MADA MEDAN
}

\author{
Bessy Sitorus Pane ${ }^{1}$, Abdul Hasan Saragih ${ }^{2}$ \\ FIK Universitas Negeri Medan ${ }^{1}$, Pascasarjana Universitas Negeri Medan ${ }^{2}$ \\ sam_bessy@yahoo.com ${ }^{1}$, ahasansaragih@gmail.com ${ }^{2}$
}

\begin{abstract}
Abstrak: Penelitian ini bertujuan untuk mengetahui; (1) hasil belajar passing atas bolavoli pada siswa yang diajar dengan gaya mengajar inklusi dengan gaya mengajar komando; (2) hasil belajar passing atas bolavoli pada siswa yang memiliki motor educability tinggi dan motor educability rendah; (3) interaksi antara gaya mengajar dan motor educability dalam mempengaruhi hasil belajar passing atas bolavoli. Populasi dalam penelitian siswa kelas VIII SMP Gajah Mada. Metode penelitian yang digunakan adalah quasi eksperimen dengan rancangan faktorial $2 \times 2$. Teknik analisis data menggunakan ANAVA $2 \times 2$. Hasil penelitian menunjukkan bahwa (1) hasil belajar passing atas bolavoli siswa yang diajar dengan menggunakan gaya mengajar inklusi lebih tinggi dari pada hasil belajar passing atas bolavoli siswa yang diajar dengan gaya mengajar komando. (2) Hasil belajar passing atas bolavoli siswa yang memiliki motor educability tinggi, lebih tinggi hasilnya daripada hasil belajar passing atas bola voli yang memiliki motor educability rendah. (3) Terdapat interaksi antara gaya mengajar dengan motor educabiliy dalam mempengaruhi hasil belajar passing atas bolavoli.
\end{abstract}

Kata Kunci: gaya mengajar, motor educability terhadap passing

Abstract: This study aims to determine; (1) The study results of passing on volleyball on students who are taught by the teaching style teaching style commando inclusion; (2) learning outcomes passing on volleyball on a motor educability students who have high and low educability motors; (3) The interaction between teaching style and the motor educability in affecting learning outcomes passing on volleyball. The population in the study class VIII SMP Gajah Mada. The method used is a quasi-experimental design with 2 $x 2$ factorial ANOVA Data were analyzed using $2 x 2$. The results showed that (1) the learning outcomes of students passing on volleyball taught using teaching style inclusion higher than on learning outcomes passing on volleyball students who are taught by the teaching style of command. (2) Results of study on volleyball passing students who have a motor educability, higher result than passing on the learning outcomes of volleyball that has a motor educability low. (3) There is an interaction between teaching style with a motor educabiliy in affecting learning outcomes passing on volleyball.

Keywords: teaching style, the motor educability against passing

\section{PENDAHULUAN}

Dalam pendidikan jasmani pendekatan/metode mengajar yang dilakukan oleh guru dikenal dengan istilah gaya mengajar. Menurut Mosston (1981) dalam proses pembelajaran penggunaan gaya mengajar merupakan hal yang penting guna tercapainya tujuan pembelajaran pendidikan jasmani. Mosston dan Ashwort (2002) mengemukakan sebelas gaya mengajar sebagai berikut: (1) gaya komando (the command style), (2) gaya latihan (the practice style), (3) gaya resiprokal (reciprocal style), (4) gaya periksa diri (the selfcheck style), (5) gaya inklusi (the inclusion style), (6) gaya penemuan terbimbing (the guided discovery style), (7) gaya penemuan konvergen (the convergent discovery style), (8) gaya produk divergen (the divergent production 
style), (9). gaya program individual (the individual program-learner design style), (10). gaya inisiatif siswa (the learner initiated style), (11). gaya mengajar sendiri/ diri (the selfteaching style)

Berdasarkan pengamatan yang dilakukan di SMP Gajah Mada Medan, guru yang mengajar ekstrakurikuler bolavoli tidak memiliki gaya mengajar yang bervariasi, karena cenderung mengandalkan gaya mengajar konvensional seperti gaya komando untuk mengajarkan semua kegiatan olahraga di lapangan. Padahal masih banyak lagi gaya mengajar yang dapat memberikan hasil yang lebih baik jika dibandingkan dengan gaya mengajar konvensional tersebut.

Pemilihan gaya mengajar komando dalam mengajar ekstrakurikuler berdasarkan wawancara dengan guru pendidikan jasmani adalah, karena gaya ini gampang untuk diterapkan. Guru tidak perlu menyiapkan pembelajaran dengan bervariasi hanya cukup mengkomando siswa untuk ikut perintah dan contoh yang diberikan oleh guru kemudian siswa melakukan gerakan yang dicontohkan oleh guru.

Dalam gaya komando tugas siswa adalah hanya meniru penampilan yang benar dari guru atau contoh dari siswa lainnya. Kurangnya pengetahuan dan keterampilan menerapkan bermacam-macam gaya mengajar mengakibatkan kegiatan ekstrakurikuler membosankan dan tidak bervariasi. Kebosanan ini dapat menghambat perolehan keterampilan dan peningkatan prestasi. Selain itu gaya mengajar komando kurang melibatkan kegiatan kognitif yang merupakan faktor yang penting dalam pembentukan rencana gerak. Kurangnya kegiatan kognitif ini antara lain para siswa tidak diberikan peran lebih, selain hanya mengikuti komando yang diberikan guru. Sehingga kurang memberi kesempatan kepada siswa untuk melakukan repetisi atau pengulangan percobaan gerakan untuk menuju penyempurnaan gerakan yang diinginkan. Kurangnya repetisi ini disebabkan karena terlalu terpusatnya kegiatan pembelajaran kepada guru, sementara siswa lebih banyak menunggu giliran untuk melakukan percobaan atau pengulangan gerakan.

Belajar gerak merupakan sebagian dari belajar secara umum. Tujuannya adalah untuk menguasai berbagai keterampilan gerak dan mengembangkannya agar keterampilan gerak yang dikuasai bisa dilakukan untuk menyelesaikan tugas-tugas gerak dalam mencapai sasaran tertentu misalnya gerak olahraga. Hal ini sesuai dengan pendapat Singer (1980), bahwa belajar gerak memiliki tujuan untuk mengembangkan berbagai keterampilan gerak secara efisien dan efektif . Setiap pembelajaran keterampilan gerak maka harus memahami tentang konsep dari belajar motorik. Pemahaman tentang belajar motorik akan memudahkan guru untuk menyusun strategi pembalajaran gerak khususnya dalam pendidikan jasmani dan olahraga. Sedangkan Singer(1980) berpendapat, bahwa belajar gerak memiliki tujuan untuk mengembangkan berbagai keterampilan gerak secara efisien dan efektif.

Lebih lanjut Singer menyatakan (1980) belajar gerak adalah suatu perubahan penampilan atau perilaku potensial yang relatif permanen sebagai hasil dari latihan dan pengalaman masa lalu terhadap situasi tugas tertentu. Drowatzcy (1981) mendefenisikan belajar gerak adalah sebagai proses perubahan atau modifikasi individu sebagai hasil timbal balik antara latihan dan kondisi lingkungan. Schmidt (1988) menjelaskan bahwa belajar gerak adalah suatu proses perubahan merespon yang relatif permanen sebagai akibat latihan dan pengalaman. Rahantoknam (1988) mendefinisikan tentang belajar motorik sebagai peningkatan dalam suatu keahlian keterampilan motorik yang disebabkan oleh kondisi-kondisi latihan atau pengalaman, dan bukan karena proses kematangan atau motivasi temporer dan fluktuasi fisiologis. Pendapat lain dikemukakan oleh Gallahue(1989) bahwa belajar atau latihan didefinisikan sebagai perubahan tingkah laku yang relatif permanen sebagai hasil dari interaksi antara latihan dan pengalaman dengan proses biologis

Metzler (2005) menyatakan, dalam proses belajar mengajar mencakup kepada tiga aspek yang harus dicapai oleh siswa, yaitu aspek kognitif, afektif dan psikomotor. Psikomotor berhubungan dengan keterampilan gerak yang harus dikuasai oleh siswa. Lebih lanjut dikatakan oleh Metzler (2005) psikomotor terpusat pada perkembangan dari keterampilan-keterampilan dan kemampuan gerak, pencapaian utama belajar adalah trampil dalam melakukan gerak. Annarino (1989) mengartikan hasil belajar atau latihan sebagai pengetahuan dan informasi. Pendapat 
tersebut sejalan dengan Khomsin (2008) menjelaskan bahwa keterampilan dalam kaitannya dengan belajar gerak dapat dibedakan menjadi dua macam, salah satunya adalah keterampilan sebagai indikator kualitas penampilan, apabila perubahan perilaku yang diukur hasilnya dikaitkan dengan indikator yang telah ditetapkan.

Proses belajar gerak menurut Lutan (1995) ada tiga tahap; 1) kognitif, merupakan fase awal dalam belajar gerak keterampilan yang bersifat mencoba, 2) Asosiatif merupakan fase menengah yang ditandai dengan tingkat penguasaan gerakan dimana belajar sudah mampu melakukan gerakan-gerakan dalam bentuk rangkaian, 3) Otonom, merupakan fase akhir pelajar mampu melakukan gerakan keterampilan secara otomatis dan mampu melakukan gerakan keterampilan tanpa pengaruh walaupun pada saat melakukan gerakan itu harus memperhatikan hal-hal yang lain.

Pendapat di atas diperkuat Fitts yang dikutip oleh Shumway dan Woollacott (2001), fase-fase belajar untuk mencapai keterampilan motorik dibagi atas tiga fase yaitu, pertama fase permulaan atau fase kognitif, kedua fase antara (intermediate) atau fase asosiatif dan ketiga fase akhir atau fase otonom.

Tahap otonom merupakan tahap yang memerlukan latihan dan waktu yang tak terbatas dan tahap akhir ini tidak semua siswa akan mencapainya. Dalam tahap automatisasi, penampilan mencapai tingkat kecakapan yang paling tinggi dan telah menjadi otomatis. Perhatian peserta didik selama tahap ini direlokasikan kepada pengambilan keputusan yang strategis. Sebagai tambahan, tugas-tugas ganda dapat dilaksanakan secara serempak. Akhirnya, siswa-siswi di dalam tahap ini bersifat konsisten, merasa yakin dan percaya diri, membuat sedikit kesalahan dan secara umum dapat mendeteksi dan mengoreksi kesalahan yang mereka lakukan (Coker, 2004).

Teori tersebut masuk ke dalam teori asosiasi stimulus-respon dari Torndike. Adapun asumsi dasar Thorndike adalah asosiasi antara kesan yang diperoleh alat indera dan impuls untuk berbuat (respon). Asosiasi kedua bagian tersebut dikenal sebagai koneksi. Thorndike memandang bahwa penguasaan keterampilan memerlukan pertautan antara stimulus dan respon yang serasi. Thorndike mengembangkan teorinya berdasarkan hasil penelitian terhadap gejala belajar "trial and error", sebagai berikut: (1) pada awal belajar sedikit sekali keberhasilan yang diperoleh; (2) respon yang salah dan aktivitas yang tidak bermanfaat lambat laun semakin berkurang; (3) pelajar semakin sadar akan koneksi yang tepat; (4) latihan memperkuat respon yang tepat dan gerakan menjadi efisien (Rusli, 1995).

Thorndike membagi hukum asosiasi stimulus respon yang mempengaruhi belajar menjadi: (1) Law of readiness; (2) Law of exercise; (3) Law of effect (Rusli, 1995).

Law of readiness atau hukum kesiapan menyatakan bahwa belajar akan berlangsung efektif bila siswa telah siap untuk menyesuaikan diri dengan stimulan dan telah siap untuk memberikan respon. Hal ini didukung oleh pendapat Ateng (1992) bahwa hukum kesiapan artinya individu akan belajar dengan cepat dan efektif apabila ia telah siaga atau siap, yakni telah matang dan telah ada kebutuhan untuk itu. Belajar akan lebih lancar jika materi yang disajikan cocok dengan kebutuhan individu. Sebaliknya individu akan terganggu dan tidak tertarik bila belum siap. Semakin individu matang mendekati kesiapan semakin memuaskan pula aktivitas yang dilakukan.

Dalam menampilkan keterampilan gerak saling berhubungan beberapa faktor. Hal ini sejalan dengan pendapat Magill (2011) yang menyatakan untuk menampilkan keterampilan gerak mempunyai hubungan dengan lingkungan, keterampilan gerak yang dipelajari dan dilatih, serta siswa yang belajar/berlatih keterampilan gerak. Berkenaan dengan siswa, salah satu faktor yang mempengaruhi adalah kesiapan siswa dalam mempelajari keterampilan gerak. Semakin baik kesiapan siswa dalam mempelajari gerak, maka hasilnya akan lebih efisien dan efektif. Sebaliknya siswa tidak memiliki kesiapan dalam belajar gerak, maka hasilnya tidak akan optimal.

$$
\text { Selanjutnya Singer }
$$

berpendapat bahwa keberhasilan dari suatu latihan tergantung kepada tingkat kesiapan siswa sebelum mengikuti kegiatan belajar. Dengan tingkat kesiapan yang memadai motivasi siswa akan timbul. Keadaan ini sangat menguntungkan bagi kesiapan pelaksanaan pembelajaran. Guru harus mengenal perbedaan 
siswa, sehingga tidak menguntungkan apabila diberikan metode latihan teknik yang sama. Guru harus memahami dengan baik proses belajar gerak, sehingga siswa menjadi percaya diri untuk belajar gerak yang bervariasi. Hal ini sejalan dengan pendapat Bloom dalam Singer (1980), yang menyatakan dalam belajar harus 1) membawa tingkah laku atau kompetensi siswa ke dalam situasi belajar, 2) meningkatkan motivasi 3) kualitas pembelajaran ( pelatih/guru yang berkualitas akan mempengaruhi motivasi siswa dan instruksi menjadi efektif.

Keterampilan pada hakekatnya adalah gerak otot atau tubuh untuk mensukseskan pelaksanaan aktivitas yang diinginkan (Singer 1982). Magil menyatakan (1998) keterampilan adalah kata yang biasa digunakan untuk menandakan suatu tugas yang mempunyai suatu tujuan spesifik yang akan dicapai. Rusli (1988) menyatakan bahwa keterampilan adalah kemampuan untuk menggunakan satu atau beberapa teknik, baik dari segi waktu maupun situasi. Keterampilan ditampilkan melalui performance yang dipelajari dan dilatih (Singer,1980). Secara garis besar keterampilan dipengaruhi oleh faktor psikologis atau emosi siswa. Lebih lanjut dikatakan Singer (1980) keterampilan dapat dikembangkan melalui latihan-latihan yang berkualitas, menghasilkan daya tanggap yang selektif dan reaksi yang cepat terhadap stimulus.

Menurut Singer (1980), keterampilan adalah perkalian antara kecepatan, ketepatan, form dan adaptasi. Kebanyakan keterampilan harus ditampilkan dengan pencapaian waktu, yaitu kecepatan. Ketepatan juga merupakan bagian dari keterampilan, untuk ketepatan gerak akan menggambarkan bagaiaman keterampilan ditampilkan. Form merupakan ekonomis gerak yang ditampilkan dengan pengunaan energy yang sedikit. Adaptasi adalah kemampuan untuk menanpilkan keterampilan dengan kondisi yang bervariasi dan yang tidak dapat diramalkan.

Keterampilan motorik dapat dibedakan menjadi dua jenis, yaitu; keterampilan motorik halus dan keterampilan motorik kasar. Seperti yang dinyatakan oleh Singer (1980) bahwa keterampilan motorik dapat dikategorikan dengan keterampilan kasar dan keterampilan halus. Lebih lanjut dinyatakan bahwa: keterampilan olahraga hampir seluruhnya menggunakan keterampilan kasar. Untuk membedakan apakah suatu gerakan tersebut sebagai keterampilan kasar dan keterampilan halus dapat diketahui dari jenis otot apa yang aktif pada saat melakukan gerakan. Untuk keterampilan kasar yang bekerja adalah jenis otot-otot besar, sedangkan untuk keterampilan halus ditandai dengan otot-otot halus saja yang bekerja

Permainan bolavoli adalah olahraga beregu yang dimainkan oleh dua regu yang masing-masing terdiri dari enam orang tiap regunya yang dipisahkan oleh net. Dimainkan dengan anggota tubuh yang didominasi oleh tangan dan lengan. Tujuan dari permainan bolavoli adalah agar setiap regu melewatkan bola melalui atas net sampai bola tersebut menyentuh lantai di lapangan lawan, dan mencegah agar bola tidak menyentuh lantai dalam lapangan sendiri.

Untuk dapat bermain bolavoli, pemain harus dapat menguasai seluruh teknik dalam permainan bolavoli. Amung dan Toto (2001) membagi teknik permainan bolavoli menjadi 6 bagian yaitu; (1) servis; (2) passing; (3) umpan; (4) spike; (5) bendungan atau block; (6) recever Sedangkan Bautelsthal (2005) mengelompokkan teknik bolavoli yaitu; (1) service, (2) pass bawah; (3) set up; (4) smash; (5) bendungan.

Passing merupakan salah satu teknik dalam permainan bolavoli dan sangat penting dan vital. Tiap regu yang memiliki pemain sehebat apapun jika tidak didukung oleh para pemain yang memiliki kualitas passing yang baik tidak dapat menang dalam permainan bolavoli. Istilah passing hampir sama dengan mengumpan sehingga keduanya di tujukan untuk memberikan bola ke teman seregunya.

Passing atas biasa disebut orang dengan setup atau umpan. Pengumpan biasanya menentukan strategi serangan, karena pengumpanlah yang memiliki kapasitas untuk itu. Variasi serangan dilakukan melalui komando seorang pengumpan sehingga pengumpan dalam permainan bolavoli memiliki posisi yang paling strategis untuk mengatur serangan. Seorang pengumpan haruslah menjadi pemain passing terbaik dari timnya (Asep, 1986). Teknik passing atas dipergunakan untuk mengumpan bola kepada penyerang. Adapun teknik pelaksanaan passing atas adalah jari-jari tangan terbuka lebar dan kedua tangan membentuk mangkuk hampir saling berhadapan. Sebelum menyentuh bola, lutut 
ditekuk hingga tangan berada dimuka setinggi hidung. Sudut antara siku dan badan lebih kurang 45 derajat (Amung dan Toto,2001)

Dalam penerapan gaya mengajar Mosston (1981) ini terdapat tiga perangkat keputusan yang menyatakan urutan mengajar dan belajar. Ketiga perangkat keputusan ini adalah : (1) sebelum pertemuan, (2) selama pertemuan, dan (3) sesudah pertemuan. Untuk itu salah satu cara untuk mengajarkan materi pendidikan jasmani di sekolah dasar agar berhasil dengan baik adalah dengan cara menggunakan gaya mengajar yang bervariasi yang dapat merangsang siswa dalam pengembangan gerak.

Memahami berbagai macam gaya mengajar menjadi satu kebutuhan seorang guru untuk (a). menghadapi jumlah siswa yang berbeda-beda, (b). tujuan pembelajaran yang mencakup ketiga ranah psikomotor, kognitif dan sosial, dan (c). Pokok masalah dan konteks yang pada waktu memberikan tugas pada suatu pendekatan yang spesifik. ( Mosston, $\mathrm{M}$ and Ashwort 2008)

Mosston dan Ashwort (2008) mengemukakan sebelas gaya mengajar, sebagai berikut: (1) gaya komando (the command style), (2) gaya latihan (the practice style), (3) gaya resiprokal (reciprocal style), (4) gaya periksa diri (the self-check style), (5) gaya inklusi (the inclusion style), (6) gaya penemuan terpimpin (the guided discovery style), (7) gaya penemuan konvergen (the convergent discovery style), (8) gaya produk divergen (the divergent production style), (9). gaya program individual (the individual program-learner design style), (10). gaya inisiatif siswa (the learner initiated style), (11). gaya mengajar sendiri/ diri (the selfteaching style).

Anatomi semua gaya mengajar terdiri dari kategori-kategori yang dapat dibayangkan tentang keputusan-keputusan yang dibuat selama proses pembelajaran. Kategori-kategori ini dikelompokkan ke dalam tiga tahap: tahap pre-impact, tahap impact, dan tahap postimpact. Pre-impact, menetapkan pembuatan semua keputusan harus dibuat sebelum interaksi belajar mengajar; impact, menetapkan keputusan-keputusan yang dihubungkan dengan interaksi belajar-mengajar yang nyata; dan post-impact menetapkan pengidentifikasian keputusan-keputusan mengenai evaluasi interaksi siswa dan guru (Bob Davis dkk,1997).
Gaya mengajar inklusi adalah pedoman mengajar yang dipakai oleh guru dalam menyajikan materi pembelajaran secara keseluruhan secara rinci dipaparkan tingkat kesulitannya ( Bob Davis dkk, 1997). Standar tugas ditentukan oleh guru, sedangkan tugas siswa adalah menunjukkan tingkatan tugas yang bervariasi untuk tugas yang sama. Siswa diberi kebebasan untuk memilih dan menentukan pada tingkat kesulitan mana siswa mulai belajar, serta diberi kebebasan juga untuk menentukan berapa kali siswa harus mengulangi gerakan dalam mempelajari suatu teknik gerakan dalam setiap pertemuan. Lebih lanjut dikatakan oleh Bob Davis dkk (1997) tujuan-tujuan dari gaya mengajar inklusi adalah siswa diberi kebebasan untuk memilih suatu tingkatan tugas untuk dapat melaksanakan dan menawarkan suatu tantangan untuk memeriksa hasil kerjanya. Intinya, tugas yang sama dirancang untuk derajat tingkat kesulitan yang berbeda. Siswa memutuskan untuk dapat menaikkan status mereka ke dalam tugas yang lebih tinggi tingkat kesukarannya lebih lanjut dipertegas oleh Jonathan Doherty (2004) gaya mengajar inklusi memaksimalkan keterlibatan siswa serta agar dapat membantu yang lain untuk berhasil dengan menggunakan rintanganrintangan yang ditetapkan pada tingkatantingkatan tertentu. Hal ini sejalan dengan pendapat Harsono (1988) Keuntungan menyajikan bahan secara keseluruhan terlebih dahulu adalah informasi dan konsep tentang materi pembelajaran dapat diberikan secara jelas dan logik mengenai keseluruhan teknik atau keterampilan. Pendapat lain yang dikemukan oleh Sugianto dan Sujarwo (1991) menyatakan bahwa apabila gerakan sifatnya sederhana lebih baik diajarkan secara menyeluruh dan apabila terdapat hubungan erat antara unsur gerakan sebaiknya menggunakan cara keseluruhan.

Gaya komando sebagai bagian dari metode belajar mengajar yang berpusat pada guru. Guru sebagai orang yang memiliki tanggung jawab terhadap keberhasilan proses belajar mengajar, sehingga guru mendominasi dalam mengambil keputusan. Seperti yang dijelaskan oleh Supandi( 1992) yang mengatakan bahwa, secara teoritis gaya komando dapat dinyatakan bahwa siswa tidak diberikan kebebasan untuk membuat keputusan sehubungan dengan proses belajarnya, inilah yang menganggap gaya komando menjadikan 
siswa sebagai objek, kebebasan siswa sangat terbatas hanya mau tidaknya mengikuti atau memenuhi perintah guru.

Mosston (1981) mengungkapkan unsur-unsur yang khas dalam pembelajaran dengan gaya komando; 1) semua keputusan dibuat oleh guru, 2) menuruti petunjuk dan melaksanakan tugas adalah merupakan kegiatan utama dari siswa, 3) menghasilkan tingkat kegiatan yang tinggi, 4) dapat membuat siswa merasa terlibat dan termotivasi, 5) mengembangkan perilaku disiplin karena mantaati prosedur yang telah ditetapkan.

Lebih lanjut Mosston dan Asworth( 2008) menyatakan dalam gaya komando tugas guru adalah membuat semua keputusan sebelum pelaksanaan ( pre-impact), pelaksanaan (impact), setelah pelaksanaan (post-impact) (evaluasi). Tugas dari peserta didik dalam mempersiapkan diri, dan mengikuti. Inti dari gaya komando ini adalah arah dan hubungan yang dekat antara stimulus guru dan respon peserta didik. Stimulus (sinyal komando) yang diberikan guru sebelumnya dalam setiap gerak peserta didik, dan peserta didik melakukan sesuai dengan apa yang dicontohkan guru. Oleh karena itu, semua keputusan mengenai tempat, gerakan, waktu mulai, pace dan ritme, waktu berakhir, durasi, dan interval dibuat oleh guru.

Motor educability adalah kemampuan motorik yang merupakan ranah psikomotorik yang intinya adalah gerakan. Motor educability merupakan kemampuan seorang individu dalam mempelajari suatu keterampilan gerak yang baru. Kemampuan ini merupakan kemampuan potensial yang menunjukkan cepat tidaknya atau mudah tidaknya seseorang menguasai suatu keterampilan gerak yang baru. Dengan kata lain dapat dinyatakan, kian tinggi tingkat motor educability seseorang maka kian mudah dan cepat orang tersebut menguasai suatu keterampilan.

Lebih lanjut dikatakan oleh Syarifudin, dan Sudarso ( 2004) pada dasarnya belajar gerak (motor learning) merupakan suatu proses belajar yang memiliki tujuan untuk mengembangkan berbagai keterampilan gerak yang optimal secara efisien dan efektif.

Menurut Agung (1991) bahwa motor educability adalah kemampuan seseorang untuk mempelajari suatu keterampilan yang baru. Cepat atau lambatnya seseorang menguasai keterampilan yang baru tersebut berkaitan denngan motor educability yang dimilikinya.
Hal ini sejalan dengan pendapat Lutan (1988) yang mengemukakan bahwa motor educability tidak dapat dipisahkan dengan intelegensi dalam rangka kegiatan belajar keterampilan seseorang. Motor educability diartikan sebagai kemampuan umum untuk mempelajari tugas secara cermat dan cepat, sering juga diistilahkan general motor intelegency. Motor educability suatu istilah yang menunjukkan kapasitas seseorang dalam mempelajari keterampilanyang sifatnya baru dalam waktu yang cepat dengan kualitas yang baik. Menurut Mathews (1985) ,motor educability dianggap sebagai indikator intelegensi dalam belajar motorik. Lebih lanjut dikatakan oleh Lutan (1988) bahwa jika seseorang memperlihatkan penampilan sedemikan cepat, menguasai suatu gerakan dengan kualitas atau kuantitas yang baik, maka orang tersebut mungkin dikatakan memiliki tingkat motor educability yang baik.

Dari uraian di atas disimpulkan bahwa orang yang dengan cepat menguasai suatu keterampilan gerak dengan kualitas yang baik berarti memiliki tingkat motor educability yang baik dan dapat mempelajari keterampilan gerak yang kualitasnya lebih sulit. Hal ini sejalan dengan pendapat Ted Baumgatner at.al, (2007) bahwa motor educability mempunyai hubungan yang berarti dengan intelegensi dan sekaligus sebagai tolak ukur dari intelegensi seseorang.

Seperti yang telah diuraikan sebelumnya bahwa intelegensi merupakan bagaimana cara seseorang berpikir, bersikap, dan bertindak, yaitu cepat atau lambatnya individu di dalam memecahkan masalah yang dihadapinya. Untuk mengetahui seberapa jauh kemampuan yang dimiliki oleh siswa dalam mempelajari suatu gerakan baru maka diperlukan alat ukur hal tersebut. Tes motor educability dimaksud untuk memprediksi kemampuan anak dalam mempelajari keterampilan gerak baru (Krikendall ,1980). Tes untuk mengukur motor educability dimaksud untuk mengukur komponen yang menjadi dasar keberhasilan anak dalam keterampilan gerak dan kognitif dimasa mendatang. Apabila siswa tidak dapat memainkan permainan dengan baik, maka sebetulnya ia belum dapat mengembangkan kecakapan gerak dengan baik (Krikendall ,1980).

Rumusan masalah dalam penelitian ini adalah sebagai berikut: (1) Apakah hasil belajar passing atas bolavoli yang diajar 
dengan gaya mengajar inklusi lebih tinggi daripada yang diajar dengan gaya mengajar komando?; (2) Apakah hasil belajar passing atas bolavoli siswa yang mempunyai motor educability tinggi lebih tinggi daripada siswa yang mempunyai motor educability rendah?; (3) Apakah terdapat interaksi antara gaya mengajar dan motor educability terhadap hasil belajar passing atas bolavoli?

\section{METODE}

Penelitian ini dilaksanakan di kelas VIII SMP Gajah Mada Medan. Uji coba alat ukur dilakukan untuk menguji kelayakan alat ukur yang akan dipergunakan. Tes pendahuluan dilakukan untuk mengumpulkan data tentang motor educability dari sampel yang dipergunakan. Selanjutnya data awal tersebut dipergunakan untuk menentukan kelompok motor educability tinggi dan motor educability rendah.

Populasi penelitian ini adalah seluruh siswa putera kelas VIII, yang terdiri dari kelas VIII A yang berjumlah 21 orang, kelas VIII B yang berjumlah 24 orang, kelas VIII C yang berjumlah 22 orang, kelas VIII D yang berjumlah 23 orang sehingga jumlah seluruh populasi adalah 90 Berdasarkan keadaan populasi tersebut akan diambil dua kelompok belajar menjadi sampel penelitian, hal ini sesuai dengan desain penelitian yang dipilih.

Dari ke 90 orang diukur tingkat motor educability-nya didasarkan pada pendapat Dali S Naga (1992) atas perhitungan sebagai berikut:
1. Kategori kelompok motor educability tinggi adalah individu yang termasuk kedalam 33 $\%$ skor tertinggi.

2. Kategori kelompok kemampuan motor educability rendah adalah individu yang termasuk kedalam $33 \%$ skor terendah.

Teknik tersebut merupakan teknik pengambilan sampel dengan membagi populasi menjadi dua kelompok yaitu sebagai kelompok yang diajar dengan gaya inklusi sebagai kelompok I dan kelompok yang diajar dengan gaya komando sebagai kelompok II di tes motor educability. Dari hasil tes tersebut diurut peringkatnya dan kemudian diambil 33\% dari atas sebagai kelompok yang memiliki motor educability tinggi dan 33\% dari bawah sebagai kelompok yang memiliki motor educability rendah.

Dari perhitungan persentasi di atas ditentukan 30 sampel untuk kelompok yang memiliki motor educability tinggi dan 30 sampel untuk kelompok yang memiliki motor educability rendah sehingga jumlah sampel seluruhnya 60 orang.

Dengan demikian diperoleh dua kelompok yang masing-masing terdiri dari: satu kelompok yang memiliki motor educability tinggi, satu kelompok yang memiliki motor educability rendah. Untuk menetapkan perlakuan terhadap masing-masing kelompok, dilakukan secara acak sehingga diperoleh dua kelompok eksperimen, yaitu kelompok yang diberikan gaya inklusi dan kelompok yang diberikan gaya komando.

Adapun rancangan penelitian yang digunakan adalah rancangan faktorial $2 \times 2$ dan dapat dilihat pada Tabel 1 berikut :

Tabel 1 Rancangan Faktorial 2 x 2

\begin{tabular}{|c|c|c|}
\hline Gaya Mengajar $(\mathrm{A})$ & Inklusi $\left(\mathrm{A}_{\mathbf{1}}\right)$ & Komando $\left(\mathrm{A}_{\mathbf{2}}\right)$ \\
\hline Motor educability $(\mathbf{B})$ & & $\mathrm{A}_{2} \mathrm{~B}_{1}$ \\
\hline Tinggi $\left(\mathrm{B}_{1}\right)$ & $\mathrm{A}_{1} \mathrm{~B}_{1}$ & $\mathrm{~A}_{2} \mathrm{~B}_{2}$ \\
\hline Rendah $\left(\mathrm{B}_{2}\right)$ & $\mathrm{A}_{1} \mathrm{~B}_{2}$ & \\
\hline
\end{tabular}

Keterangan :
$\mathrm{A}_{1}=$ Gaya mengajar inklusi secara keseluruhan
$\mathrm{A}_{2}=$ Gaya mengajar komando secara keseluruhan
$\mathrm{B}_{1}=$ Kelompok motor educability tinggi
$\mathrm{B}_{2}=$ Kelompok motor educability rendah
$\mathrm{A}_{1} \mathrm{~B}_{1}=$ Hasil belajar kelompok siswa motor educability tinggi dengan perlakuan gaya mengajar inklusi
$\mathrm{A}_{2} \mathrm{~B}_{\mathrm{I}}=$ Hasil belajar kelompok siswa motor educability tinggi dengan perlakuan gaya mengajar komando
$\mathrm{A}_{\mathrm{I}} \mathrm{B}_{2}=$ Hasil belajar kelompok siswa motor educability rendah dengan


perlakuan gaya mengajar inklusi

$\mathrm{A}_{2} \mathrm{~B}_{2}=$ Hasil belajar kelompok siswa motor educability rendah dengan perlakuan gaya mengajar komando

Untuk pengumpulan data penelitian perlu ditentukan teknik pengumpulan data. Teknik pengumpulan data pada penelitian ini menggunakan teknik tes. Teknik pengumpulan data akan dilakukan dengan cara tes motor educability dengan menggunakan tes baku IOWA BRACE-test . Untuk mengukur teknik passing atas dengan menggunakan validitas ahli dimana akan dikonsultasikan dengan 3 orang ahli permainan bolavoli.

Teknik analisis data menggunakan teknik Analisis Varians (ANAVA) dua jalur dan dilanjutkan dengan uji lanjut yang menggunakan uji Tukey, dengan taraf kepercayaan $\alpha=0,05$. Sebelum data diolah menggunakan analisis varians (ANAVA) dilakukan uji persyaratan ANAVA, yaitu uji normalitas menggunakan uji Lilifors, dan Uji
Homogenitas Varians menggunakan Uji Barlett, dengan taraf kepercayaan $\alpha=0,05$.

Adapun hipotesis yang diuji dalam penelitian ini adalah sebagai berikut:

$$
\begin{array}{ll}
\text { Pertama; } & \mathrm{H}_{0}: \mu_{\mathrm{A} 1}=\mu_{\mathrm{A} 2} \\
& \mathrm{H}_{1}: \mu_{\mathrm{A} 1}>\mu_{\mathrm{A} 2} \\
\text { Kedua; } & \mathrm{H}_{0}: \mu_{\mathrm{B} 1}=\mu_{\mathrm{B} 2} \\
& \mathrm{H}_{1}: \mu_{\mathrm{B} 1}>\mu_{\mathrm{B} 2} \\
\text { Ketiga; } & \mathrm{H}_{0}: \mathrm{Gm}><\mathrm{ME}=0 \\
& \mathrm{H}_{1}: \mathrm{Gm}><\mathrm{ME}=0
\end{array}
$$

\section{HASIL DAN PEMBAHASAN \\ Hasil}

Pengujian hipotesis dilakukan dengan menggunakan tehnik Analisis Varians (ANAVA). Untuk keperluan analisis varians, data-data yang diperlukan dapat dilihat pada tabel 4.16 sedangkan data-data lengkap terdapat pada bagian lampiran penelitian ini.

\begin{tabular}{|c|c|c|c|c|}
\hline \multirow{2}{*}{\multicolumn{2}{|c|}{ Variabel }} & \multicolumn{2}{|c|}{ Gaya mengajar Mengajar } & \multirow{2}{*}{ Total } \\
\hline & & Inklusi & Komando & \\
\hline \multirow{2}{*}{$\begin{array}{c}\text { Motor } \\
\text { educability }\end{array}$} & Tinggi & $\begin{aligned} \mathrm{n} & =15 \\
\overline{\mathrm{x}} & =38.93 \\
\sum \mathrm{x} & =584 \\
\sum \mathrm{x}^{2} & =23374 \\
\mathrm{SD} & =6.01\end{aligned}$ & $\begin{aligned} \mathrm{n} & =15 \\
\overline{\mathrm{x}} & =23.67 \\
\sum \mathrm{x} & =355 \\
\sum \mathrm{x}^{2} & =8651 \\
\mathrm{SD} & =4.02\end{aligned}$ & $\begin{aligned} \mathrm{n} & =30 \\
\overline{\mathrm{x}} & =31.3 \\
\sum \mathrm{x} & =929 \\
\sum \mathrm{x}^{2} & =32025 \\
\mathrm{SD} & =5.01\end{aligned}$ \\
\hline & Rendah & $\begin{aligned} \mathrm{n} & =15 \\
\overline{\mathrm{x}} & =24.87 \\
\sum \mathrm{x} & =373 \\
\sum \mathrm{x}^{2} & =9467 \\
\mathrm{SD} & =3.74\end{aligned}$ & $\begin{aligned} \mathrm{n} & =15 \\
\overline{\mathrm{x}} & =26.13 \\
\sum \mathrm{x} & =393 \\
\sum \mathrm{x}^{2} & =10392 \\
\mathrm{SD} & =3.64\end{aligned}$ & $\begin{aligned} \mathrm{n} & =30 \\
\overline{\mathrm{x}} & =25.5 \\
\sum \mathrm{x} & =765 \\
\sum \mathrm{x}^{2} & =19859 \\
\mathrm{SD} & =3.70\end{aligned}$ \\
\hline \multicolumn{2}{|c|}{ Total } & $\begin{aligned} \mathrm{N} & =30 \\
\mathrm{x} & =31.9 \\
\Sigma \mathrm{x} & =957 \\
\sum \mathrm{x}^{2} & =32841 \\
\mathrm{SD} & =4.85\end{aligned}$ & $\begin{array}{l}\mathrm{N}=30 \\
\overline{\mathrm{x}}=24.9 \\
\sum x=747 \\
\sum \mathrm{x}^{2}=19043 \\
\mathrm{SD}=3.83\end{array}$ & $\begin{aligned} \mathrm{N} & =60 \\
\mathrm{x} & =28.4 \\
\Sigma \mathrm{x} & =1704 \\
\sum \mathrm{x}^{2} & =51884\end{aligned}$ \\
\hline
\end{tabular}
Hasil perhitungan yang diperoleh dirangkum dalam tabel perhitungan analisis varians seperti pada tabel berikut ini:

Tabel 2. Rangkuman data hasil penelitian

Tabel 3. Hasil perhitungan ANAVA

\begin{tabular}{|c|c|c|c|c|c|}
\hline Sumber Varians & $\begin{array}{c}\text { Jumlah } \\
\text { Kuadrat (JK) }\end{array}$ & dk & $\begin{array}{c}\text { Rata-rata Jumlah } \\
\text { Kuadrat (RJK) }\end{array}$ & F hitung & $\begin{array}{c}\text { F tabel } \\
\mathbf{\alpha = 0 , 0 5}\end{array}$ \\
\hline Antar kolom & 735 & 1 & 735 & 33.58 & 4,01 \\
Antar baris & 504.6 & 1 & 504.6 & 23.05 & 4,01 \\
Interaksi & 1025.07 & 1 & 1025.07 & 46,83 & 4,01 \\
\hline
\end{tabular}




\begin{tabular}{|c|c|c|c|c|c|}
\hline Antar kelompok & 2264.67 & 3 & - & - & - \\
Dalam kelompok & 1225.73 & 56 & 21.89 & - & - \\
\hline Total & 3490.4 & 60 & - & - & - \\
\hline
\end{tabular}

Untuk menguji apakah hasil belajar passing atas bolavoli yang diajar dengan gaya mengajar Inklusi berbeda dari pada keterampilan passing atas bola voli siswa yang diajar dengan gaya mengajar komando, maka digunakan tehnik analisis varians (ANAVA). Pengujian dilakukan terhadap hipotesis statistik :

$\mathbf{H}_{0}: \mu_{A 1}=\mu_{A 2}$

$\mathbf{H}_{a}: \mu_{A 1}=\mu_{A 2}$

Berdasarkan data yang diperoleh juga menunjukkan bahwa nilai rata-rata hasil belajar passing atas bolavoli siswa yang diajar dengan gaya mengajar inklusi $(31,9)$ lebih tinggi daripada hasil belajar passing atas bolavoli yang diajar dengan gaya mengajar komando $(24,9)$. Dari hasil perbandingan nilai rata-rata dan pengujian ANAVA yang diperoleh dapat disimpulkan hasil belajar passing atas bolavoli siswa yang diajar dengan gaya mengajar inklusi berbeda dengan siswa yang diajar dengan gaya mengajar komando.

Pengujian apakah hasil belajar passing atas bolavoli yang memiliki motor educability tinggi berbeda dengan hasil belajar passing atas bola voli yang memiliki motor educability rendah, juga dilakukan dengan menggunakan tehnik analisis varians (ANAVA). Pengujian dilakukan terhadap hipotesis statistik :

$\mathbf{H}_{0}: \mu_{B 1}=\mu_{B 2}$

$\mathbf{H}_{a}: \mu_{B 1}>\mu_{B 2}$

Berdasarkan data yang diperoleh juga menunjukkan bahwa nilai rata-rata hasil belajar passing atas bolavoli siswa yang memiliki motor educability tinggi $(31,3)$ lebih tinggi secara signifikan daripada hasil belajar keterampilan passing atas bolavoli siswa yang memiliki motor educability rendah $(25,5)$. Dari hasil perbandingan nilai rata-rata dan pengujian ANAVA yang diperoleh dapat disimpulkan hasil belajar passing atas bola voli yang memiliki motor educability tinggi lebih tinggi secara signifikan daripada hasil belajar passing atas bolavoli yang memiliki motor educability rendah.

Pengujian ada tidaknya interaksi antara metode mengajar dengan motor educabiliy dalam mempengaruhi hasil belajar passing atas bola voli juga menggunakan tehnik analisis varians (ANAVA). Pengujian dilakukan terhadap hipotesis statistik :

$\mathbf{H}_{0}: \mathbf{A} \times \mathbf{B}=\mathbf{0}$

$\mathbf{H}_{a}: \mathbf{A} \times \mathbf{B}=\mathbf{0}$

Dari hasil perhitungan dengan tabel ANAVA pada tabel 4.17 diperoleh bahwa $\mathrm{F}_{\text {hitung }}=46.83$ dan $\mathrm{F}_{\text {tabel }}=4,01$ pada taraf signifikansi 0,05. Hal ini berarti bahwa $\mathrm{F}_{\text {hitung }}$ $>\mathrm{F}_{\text {tabel }}$, menunjukkan bahwa hipotesis nol (Ho) ditolak dan hipotesis alternatif (Ha) diterima. Dengan demikian bahwa hipotesis penelitian yang menyatakan terdapat interaksi antara gaya mengajar dan motor educability dalam mempengaruhi hasil belajar passing atas bolavoli teruji kebenarannya.

Berdasarkan hasil pengjuian hipotesis di atas dapat juga dilihat bahwa ada interaksi antara gaya mengajar dan motor educability terhadap hasil belajar keterampilan passing atas bola voli siswa. Interaksi antara gaya mengajar dengan motor educabiliy dapat dilihat pada gambar berikut : 


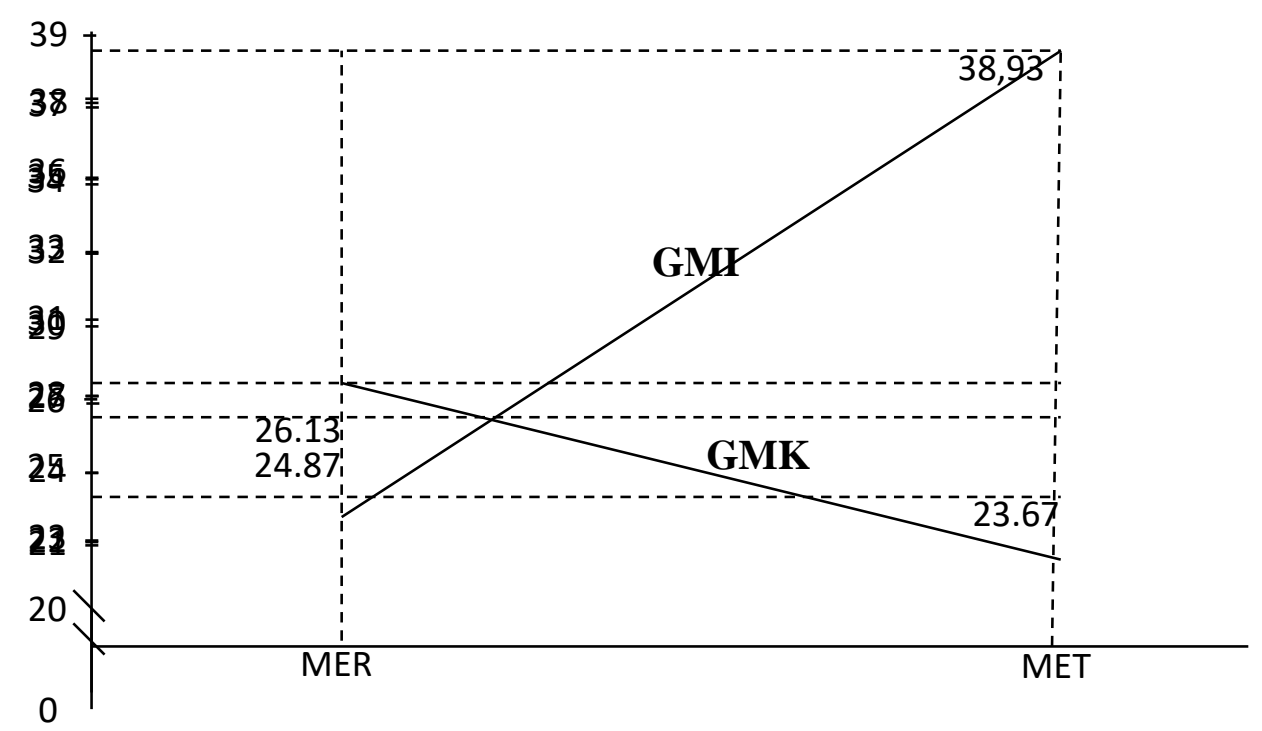

Gambar 1 Diagram interaksi antara gaya mengajar dengan Motor Educability terhadap hasil belajar keterampilan Passing atas bolavoli.

Adanya interaksi antara gaya mengajar dan motor educability dalam mempengaruhi hasil belajar passing atas bolavoli serta data yang diperoleh dalam penelitian ini berasal dari sampel yang jumlahnya sama dalam sel ANAVA, maka perlu diadakan uji lanjut dengan menggunakan uji Tuckey. Hasil perhitungan uji lanjut dapat dilihat pada tabel berikut ini:

Tabel 4. Ringkasan hasil perhitungan uji lanjut (Uji Tuckey)

\begin{tabular}{|c|c|c|c|}
\hline \multirow{2}{*}{ Niilai kelompok yang dibandingkan } & \multirow{2}{*}{ F $_{\text {hitung }}$} & \multicolumn{2}{|c|}{$\mathbf{F}_{\text {tabel }}(\mathbf{3 , 5 6})$} \\
\cline { 3 - 4 } & & $\mathbf{\alpha = \mathbf { 0 , 0 5 }}$ & $\boldsymbol{\alpha = \mathbf { 0 , 1 }}$ \\
\hline$\mu_{11}$ dengan $\mu_{12}$ & 11.62 & 2,83 & 3,76 \\
\hline$\mu_{11}$ dengan $\mu_{21}$ & 10.96 & 2,83 & 3,76 \\
\hline$\mu_{11}$ dengan $\mu_{22}$ & 3.74 & 2,83 & 3,76 \\
\hline$\mu_{21}$ dengan $\mu_{22}$ & 2.03 & 2,83 & 3,76 \\
\hline$\mu_{21}$ dengan $\mu_{12}$ dengan $\mu_{22}$ & 1.05 & 2,83 & 3,76 \\
\hline$\mu_{12}$ den & 1.2 & 2,83 & 3,76 \\
\hline
\end{tabular}

\section{Pembahasan}

Berdasarkan hasil-hasil perhitungan dalam penelitian yang diperoleh, terlihat bahwa hasil belajar passing bawah bolavoli siswa yang diajarkan dengan gaya inklusi lebih baik jika dibandingkan dengan hasil belajar passing atas bolavoli yang diajarkan dengan gaya komando . Hal ini dimungkinkan karena dengan gaya inklusi, siswa tidak merasa terbeban atau terpaksa. Sebab dengan gaya inklusi mereka diberikan kebebasan untuk melakukan suatu gerakan ataupun keterampilan dengan kemampuan yang mereka miliki dan siswa lebih tertarik dalam mempelajari suatu keterampilan ataupun gerakan dalam pembelajaran pendidikan jasmani. Siswa diberikan pilihanpilihan untuk mengulangi keterampilan sesuai dengan pilihan dan keinginan mereka sendiri dengan kata lain mereka dapat bereksplorasi gerakan yang diinginkan oleh mereka sendiri Jadi pada dasarnya pembelajaran yang diberikan dengan gaya mengajar inklusi diyakini keunggulannya dalam meningkatkan hasil belajar passing atas bolavoli. Untuk siswa yang memperoleh pembelajaran dengan gaya inklusi, merasakan adanya kebebasan dalam melakukan suatu gerakan dan mengulanginya tanpa adanya keterpaksaan dari guru untuk melakukannya. Dengan kata lain siswa yang diajarkan dengan gaya inklusi ini tidak menyadari bahwa siswa telah diberikan kepercayaan untuk melakukan gerakan sesuai dengan kebutuhan dirinya, dan ia akan menemukan sendiri kesulitan-kesulitan yang nantinya akan dicari pemecahannya dengan berdiskusi dengan guru. Tidak seperti selama 
ini dimana siswa untuk melakukan suatu gerakan -gerakan secara bagian-bagian melalui instruksi dari guru, dengan kata lain siswa menjadi pasif dan hanya menunggu perintah dari guru.

Selain kenyataan yang dihadapi dalam penerapan gaya mengajar inklusi tersebut, sejalan dengan temuan dalam penelitian ini telah menguatkan bahwa hasil belajar passing atas bolavoli siswa yang diajarkan dengan gaya inklusi lebih tingi secara signifikan dari hasil belajar passing atas bolavoli siswa yang diajarkan dengan gaya mengajar komando.

Berdasarkan data yang diperoleh telah menunjukan bahwa nilai rata-rata hasil belajar passing atas bolavoli melempar siswa yang diajarkan dengan gaya inklusi ( 31.9 ) lebih tinggi daripada hasil belajar passing atas bolavoli siswa yang diajar dengan gaya komando (24.9). Dari hasil perbandingan ratarata yang diperoleh memberikan simpulan bahwa hasil perbandingan rata-rata hasil belajar passing atas bolavoli siswa yang diajarkan dengan gaya inklusi lebih baik dari hasil belajar passing atas bolavoli yang diajarkan dengan gaya komando. Hal ini sesuai dengan dugaan sebelumnya yang menggunggulkan gaya mengajar inklusi dalam pembelajaran passing atas bolavoli . Keunggulan dari gaya inklusi yang dipaparkan dalam kerangka berpikir terbukti secara empiris di lapangan, sehingga hasil ini telah menguatkan bahwa dengan gaya inklusi hasil belajar passing atas bolavoli lebih baik.

Dalam mempelajari suatu gerak, keterampilan, maupun melakukan suatu aktivitas setiap siswa berbeda-beda dalam melakukannya. Ada yang suka melakukan aktivitas-aktivitas dengan gerakan-gerakan yang bervariasi dan berulang-ulangi, ada yang melakukan suatu gerakan kalau diperintah oleh guru dan menirukan apa yang dilakukan oleh guru, hal ini tergantung dari tingkat motor educability yang dimiliki masing-masing orang karena setiap orang mempunyai tingkat motor educability yang berbeda-beda pula. Demikian juga dalam belajar passing atas bola voli, ada siswa dengan mudah mempelajari keterampilan passing atas bolavoli, hal ini berhubungan dengan kognitif gerak, yang berhubungan dengan kemudahan-kemudahan belajar gerak passing atas bolavoli tersebut. Semakin baik tingkat motor educability maka akan semakin mudah dan cepat dalam belajar passing atas bolavoli.

Motor educability siswa merupakan karakteristik yang dimiliki oleh siswa, yang harus menjadi pengetahuan yang dimiliki guru dalam mengajarkan suatu gerakan, sehingga guru dapat merencanakan gaya mengajar yang tepat yang akan digunakan dan disesuaikan dengan tingkat motor educability siswa. Karena setiap siswa mempunyai tingkat motor educability yang berbeda-beda pula.

Bagi yang memiliki motor educability tinggi akan suka diberi kebebasan untuk melakukan aktivitas-aktivitas sesuai dengan tingkat kesulitan yang diinginkan, dan pengulangan sesuai dengan keinginanan siswa. Guru hanya memberikan pilihan-pilihan gerakan passing atas dan siswa diberi kebebasan untuk latihan passing atas dimulai dari gerakan yang paling sulit ataupun dimulai dari gerakkan yang mudah, memilih tempat/ lokasi latihan, mandiri ataupun berkelompok. Disamping itu siswa diberi kebebasan untuk berapakali dalam melakukan pengulangan geakan tersebut.

Bagi siswa yang memiliki motor educability tinggi umumnya tidak bisa diam dan selalu aktif dan kreatif dalam mempelajari suatu gerakan, sehingga diharapkan hasil belajar passing atas bolavoli akan lebih baik atau lebih tinggi dari hasil belajar passing atas bolavoli siswa yang memiliki motor educability rendah. Hal ini terbukti secara empiris dilapangan bahwa hasil belajar passing atas bolavoli siswa yang memiliki motor educability lebih tinggi dari hasil belajar passing atas bolavoli siswa yang memiliki motor educability rendah Hasil temuan menunjukkan bahwa rata-rata hasil belajar passing atas bolavoli siswa yang memiliki motor educability tinggi $(31,3)$ lebih tinggi dari hasil belajar passing atas bolavoli siswa yang memiliki motor educability rendah (25.5).

Kebenaran hasil ini memberikan indikasi bahwa pembelajaran dengan gaya inklusi lebih unggul digunakan untuk pembelajaran passing atas bolavoli pada siswa yang memiliki motor educability tinggi. Namun bukan berarti tidak baik digunakan dalam belajar passing atas terhadap siswa yang memiliki motor educability rendah.

\section{PENUTUP}

Berdasarkan hasil penelitian dan pembahasan yang telah diuraikan pada bab 
sebelumnya, maka diambil simpulan sebagai berikut :

1. Hasil belajar passing atas dalam pembelajaran bolavoli siswa yang diajar dengan menggunakan gaya mengajar inklusi berbeda dengan gaya mengajar komando .

2. Hasil belajar passing atas dalam pembelajaran bolavoli siswa yang memiliki motor educability tinggi berbeda dengan siswa yang memiliki motor educability rendah.

3. Terdapat interaksi antara gaya mengajar dan motor educability terhadap hasil belajar passing atas dalam pembelajaran bolavoli siswa. Untuk siswa yang memiliki motor educability tinggi lebih efektif dalam meningkatkan hasil belajar passing atas jika menggunakan gaya inklusi, sedangkan untuk siswa yang memiliki motor educability rendah ternyata gaya mengajar komando lebih efektif dalam meningkatkan motor educability dibandingkan jika menggunakan gaya inklusi.

\section{DAFTAR PUSTAKA}

Makmum, Amung \& Subroto, Toto. 2001. Pendekatan Keterampilan Taktis dalam Pembelajaran Bolavoli. Jakarta: Depdiknas, Dirjen Dikdasmen, Dirjen Olahraga.

Anthony Annarino A, Charles C. Cowell and Helen W. Hazelton. 1980. Curriculum Theory and Design in Physical Education. St Louis: C.V.Mosby Company.

Asep. 2008. Melatih Bolavoli Remaja, diterjemahkan oleh Novi Lestari. Jakarta: Citra Aji Parama.

Baumgatner Ted,Andrew S Jackson. 2007. Matthew T Mahar, David A Rowe, Measurment For Evaluation in Physical Education \& Exercise Science. New York: Mcgraw-Hill Companies,Inc.

Beutelstahl, Dieter. 2005. Belajar Bermain Bola Volley. Bandung: CV Pioner Jaya.

Blough Steven R. 2006. A Renaisssance of Modern Movement : A Footbag-hacky sack-Research paper about eye/foot coordination benefit.

Bompa, Tudor O. 1999. Theory and Methodology of Training the Key to Athletic Performance. New York: Kendall/Hunt Publishing Company.
Borg, Walter R. \& Meredith D. Gall. 1983. Education Research: an Introduction, New York: Longman Inc.

Coker, Cheryl A. 2004. Motor Learning and Control for Practitioners, USA: Library of Congres Cataloging in Publication Data.

Cook Anne Shumway dan Marjorie H.Woollacott. 2001. Motor Control.Theory And Practical Applications, Amerika : Lippincott Williams \& Wilkins.

Hidayat, Cucu. 2008. Model Inklusi Dalam Pembelajaran Pendidikan Jasmani, (http://educare.e-fkipunla.net).

Emzir. 2008. Metodologi Penelitian Pendidikan. Jakarta: PT.Raja Grafindo Persada.

David C Neiman, 1990. Fitness and Sport Medicine An Introduction. California : Bull Publishing Company.

Davis, Bob et al. 1997. Physical Education And The Study of Sport. London: Mosby, an imprint of Times Mirror International Publisher Ltd.

Donall, Mathews K. 1985. Measurment in Physical Education, London, Philedephia: Sauders Company.

Drowatzky, John N. 1981 Motor Learning: Principle and Practice, 2nd, Ed. Minneapolis: Minnesota: Burgess Publishing Company.

Fallowfield Joanne L, Beverley J.Hale, dan David M.Wilkinson. 2005. Using Statistic in Sport and Exercise Science Research . England: Lotus Publishing.

Foran Bill , 2001. High Performance Sport Conditioning. Amerika Serikat: Human Kinetics Publisher, Inc.

Gallahue David L dan Jhon C.Ozmun. 2006. Understanding

Motor

Development.Infants, Children, Adolescents, Adult. New York: McgrawHill.

Glass, Gene V. and Kennet D. Hopkins. 1984. Statistical Methods in Education and Psychology, Englewood Cliffs: Prentie Hall.

Harrow Anita J. 1972 A Taxonomy of The Pshycomotor Domain, New York: Longman Inc.

Harsono. 1988. Coaching dan Aspek Psikologis dalam Coaching. Jakarta: P2LPTK, Ditjendikti, Depdikbud. 
Hurlock, Elizabeth B. 1990. Psikologi Perkembangan-Suatu Pendekatan Rentang Kehidupan. Terjemahan lstimiwidayanti dan Soedjarwo, Jakarta: Erlangga.

Kirkendall Don R, Joseph J. Gruber, Robert E Jhonson. 1980. Measurement and Evaluation For Physical Educator , Dubuque Iowa: Wm.C.brown Company Publisher.

Magil, Ricard A. 1998. Motor Learning: Concepts and Applications, Singapore: A Division of the Mc. GrawHill. Companies.

Mc.Cloy Charles Harold \& Norma Dorothy Young. 1984. Test and Measurement in Health And Physical Education. New York : Appleton Century Crofts Inc.

Metzler Michael W. 2005. Instructional Models For Physcal Eduacation. Arizona: Holcomb Hathaway Publisher.

Sumantri, Mulyani \& Saodih, Nana. 2000. Perkembangan Peserta Didik. Jakarta :Universitas Terbuka.

Mosston M. 1981. Teaching Physical Education (2nd ed), Columbus, $\mathrm{OH}$ : Merrill.

Mosston M dan Ashworth S. 2008. Teaching Physical Education.First Online Edition.

Mosston, M and Ashwort, S. 1994. Teaching Physical Education (4th ed). New York: Mac Millan College Publishing Inc.

Teaching Physical Education 5th ed 2002. dikutip langsung (atau tidak langsung) oleh Mark Byra, Teachings style and inclusive pedagogis. David Kirk, et
al.The Hand Book Physical Education, London: SAGE Publication, 2006.

Muhibbin Syah. 2004. Psikologi Belajar. Jakarta: PT.Raja Grafindo Persada.

Pyke, Frank S. 1991. Better Coaching: Advanced Coach Mannual. Canberra: Australian Coaching Councyl Incorporated.

Robert, Gagne. M. 1987. The Conditions of Learning. Third Edition New York: Holt Rinehart and Winston.

Sage, George H. 1984. Motor Learning and Control a Behavioral Emphasis, Champaign: Human Kinetics Publisher, Inc.

Samsudin. 2008. Pembelajaran Pendidikan Jasmani Olahraga dan Kesehatan, Jakarta: Litera.

Schmidt, Richard A. 1988. Motor Learning and Control: a Behavior Emphasis, Champion. Illinois: Human Kinetics Publishers Inc.

Singer, Robert N. 1982. The Learning of Motor Skill. New York: Macmillan Publishing Co.

Syarifudin dan Sudarso . 2004. Jurnal IPTEK Olahraga. Vol.6 No 1 Januari.

Thompson, Peter J.L. 1991. Introduction to Coaching Theory, England: International Amateur Athletic Federation.

Verducci, Frank M. 1980. Measurement Concept in Physical Education. St. Louis Missouri: Mosby Company.

Viera ,Barbara L. MS \& Bonniee Jill Fergusson, MS. 2004. Bolavoli Tingkat Pemula diterjemahkan oleh: Monti. Jakarta: PT Raja Grafindo Persada. 